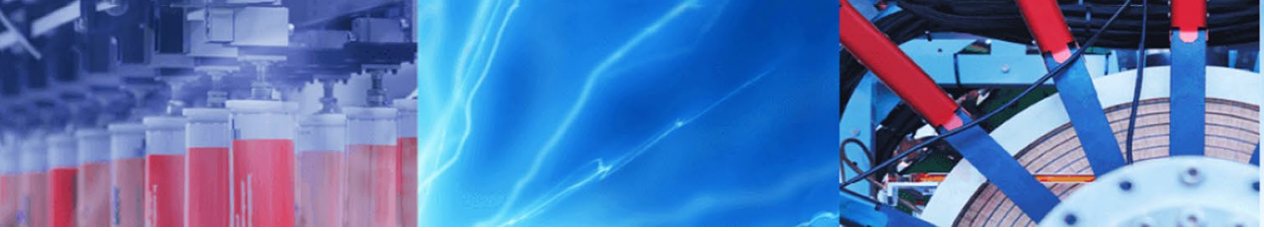

Research Article

\title{
The biochars prepared from cinnamon and cannabis as nature-friendly adsorbents for removal of $\mathrm{Cd}(\mathrm{II})$ ions from aqueous solutions
}

\author{
A. H. Omidi ${ }^{1} \cdot$ M. Cheraghi $^{1}$ (D) B. Lorestani ${ }^{1} \cdot$ S. Sobhanardakani ${ }^{1} \cdot$ A. Jafari $^{2}$
}

Received: 6 March 2020 / Accepted: 22 May 2020 / Published online: 4 June 2020

(c) Springer Nature Switzerland AG 2020

\begin{abstract}
Cinnamon and cannabis were utilized to produce biochars, which operate as promising adsorbents by pyrolysis in various temperatures using the $\mathrm{N}_{2}$ atmosphere. The novel biochars were analyzed via scanning electron microscopy, X-ray powder diffraction, Fourier-transform infrared spectroscopy, the $\mathrm{pH}$ point of zero charges, and $\mathrm{N}_{2}$ adsorption-desorption isotherm styles, followed by testing the adsorption attributes of these materials using $\mathrm{Cd}$ (II) ions in a water bath. The $\mathrm{Cd}(\mathrm{II})$ adsorption onto biochars was satisfied in the neutral $\mathrm{pH}$ of 7.0 and a temperature of $65^{\circ} \mathrm{C}$. The equilibrium data in aqueous solutions were fitted to Langmuir (L), Freundlich ( $F$ ), Tempkin $(T)$, and Redlich-Peterson (R-P) models. Kinetic adsorption data were analyzed using the pseudo-first-order (PFO), pseudo-second order (PSO), Elovich (E), and intraparticle diffusion (ID) models. In addition, the Cd(II) adsorption performance was proficiently narrated through Langmuir and pseudo-second-order models and electrostatic force and chemical reaction were originally responsible for adsorption mechanism. Further, the results demonstrated that the obtained $\mathrm{q}_{\max }$ from biochars at the pyrolysis temperature of $600{ }^{\circ} \mathrm{C}$ was higher than that noticed at pyrolysis temperatures of 300 and $400{ }^{\circ} \mathrm{C}$. Finally, the adsorbent dose of $0.1 \mathrm{~g}$ and temperature of $65^{\circ} \mathrm{C}$, as well as supplying $\mathrm{q}_{\max }$ of $147.05,153.84,158.73,133.33,144.92$, and $175.43 \mathrm{mg} \mathrm{g}^{-1}$ were observed for cinnamon 300 , cinnamon 400 , cinnamon 600 , cannabis 300 , cannabis 400 , and cannabis 600 , respectively.
\end{abstract}

Keywords Adsorption · Biochar · Cadmium · Kinetic · Pyrolysis

\section{Introduction}

The pollution of water, sediments, and soils by heavy metal release into the natural environment has become a critical and controversial topic for different industrial factories worldwide [1, 2]. Recent national and international legislation for improving the quality of drinking water are getting tougher due to the variety of pollutant sources. Heavy metals have irreversible damages on the growth of plants and they can lead to the inactivation of numerous enzymes, as well as the destruction of some proteins in the animals and human bodies [3]. Among various metals such as lead $(\mathrm{Pb})$, mercury $(\mathrm{Hg})$, cadmium (Cd), arsenic (As), and vanadium (V), Cd is considered as one of the most perilous metals, which can accumulate by food chain and can be a reason for chronic and acute poisoning [4-6]. In addition, the toxicity and non-degradable of this metal cause nausea, diarrhea, bone malformation, kidney damage, and cancer [4-6]. The World Health Organization has set a maximum concentration of $0.05 \mu \mathrm{g} \mathrm{L}^{-1} \mathrm{Cd}$ in drinking water [7]. So far, previous studies have utilized various traditional approaches to eliminate $\mathrm{Cd}$ ions from water, including reverse osmosis, chemical precipitation, flocculation, and ion exchange [8]. Although these strategies can be executable and beneficial, they have high operation and substructure costs and produce large amounts of toxic intermediate materials. The adsorption is unique due to

$\triangle$ M. Cheraghi, mhrdadc613@gmail.com | 'Department of the Environment, College of Basic Sciences, Hamedan Branch, Islamic Azad University, Hamedan, Iran. ${ }^{2}$ Department of Physics, College of Basic Sciences, Hamedan Branch, Islamic Azad University, Hamedan, Iran. 
some marvelous features such as simplicity, effective, and low-energy consumption [9].

Biochars are considered as a group of carbon materials, which are ordinarily fabricated by pyrolysis various biomasses as feedstock (e.g., wood, sawdust, food, and agricultural wastes) under oxygen-limited situations and a high temperature $[10,11]$. These materials can be utilized as an adsorbent due to the large surface area, microporosity, functional groups, and hydrophobicity. However, some chemical and physical characteristics of biochars change with pyrolysis temperature and biomass kind. For example, the amount of dissolved organic carbon in biochar obtained from low temperature was higher compared to high temperature $[12,13]$. Biochar mainly includes different compounds (e.g., aliphatic and aromatic) and main functional groups (e.g., hydroxyl, carbonyl, and phenolic hydroxyl groups), that lead to their excellent adsorption capacity for adsorption organic and inorganic pollutants as an inexpensive substitute for the activated carbon. Also, the type of biochar depends on the pyrolysis temperature. When the pyrolysis temperature is too high, the microstructure of biochar develops. However, loss of functional group and carbon on the surface is excessive [14, 15].

Different studies focused on the supreme adsorption capacity of biochar toward heave metals. For instance, [16]. Reported the $\mathrm{Cr}(\mathrm{VI})$ removal using biochar produced from Eucalyptus plant bark at $500^{\circ} \mathrm{C}$. The results indicated that biochar has enormous potentials for $\mathrm{Cr}(\mathrm{VI})$ ion removal from water samples. Further, [17]. Demonstrated the elimination of heavy metals via modified biochar from different wastewater and concluded that prepared biochar is considered as an effective adsorbent for removing heavy metals from water.

In the present study, a facile, quick, and economic technique was explained for obtaining biochars with great surface area and porous structure from cinnamon and cannabis seed. Also, the biochars obtained from cinnamon and cannabis seeds is one of the most abundant renewable resources that include carbon, nitrogen, potassium, and calcium. Then, the surface of biochars was activated by hydrogen chloride as the oxidation agent and was utilized as the adsorbent to eliminate $\mathrm{Cd}$ (II) ions from water. Furthermore, the adsorption equilibrium test information was modeled using isotherm (Langmuir, Freundlich, Temkin, and Redlich-Peterson) and kinetic (pseudo-first-order, pseudo-second-order, Elovich, and the intraparticle diffusion) models. Additionally, the adsorption parameters such as the $\mathrm{pH}$ of $\mathrm{Cd}$ (II) solution, adsorbent dose, reaction time, and temperature were evaluated in detail, followed by discussing the regeneration potential of biochars.

\section{Materials and methods}

\subsection{Apparatus and reagents}

The cinnamon and cannabis seeds were used as raw materials for biochar production taken from markets in Iran. In addition, hydrogen chloride $(\mathrm{HCl})$, sodium hydrate $(\mathrm{NaOH})$, nitric acid $\left(\mathrm{HNO}_{3}\right)$, ethanol $\left(\mathrm{C}_{2} \mathrm{H}_{6} \mathrm{O}\right)$, and cadmium nitrate $\left(\mathrm{Cd}\left(\mathrm{NO}_{3}\right)_{2} \cdot 4 \mathrm{H}_{2} \mathrm{O}\right)$ were supplied from Merck (Germany). Further, the $\mathrm{Cd}$ (II) stock solution was provided with $\mathrm{Cd}\left(\mathrm{NO}_{3}\right)_{2} \cdot 4 \mathrm{H}_{2} \mathrm{O}$ and deionized water.

The contents of $\mathrm{Cd}(\mathrm{II})$ were examined by inductively coupled plasma-optical emission spectrometry (ICP-OES, JY138 ultrace, France). Furthermore, scanning electron microscopy (SEM-EDX, XL30, and Philips Netherlands), X-ray powder diffraction (38066 Riva, d/G.Via M. Misone, $11 / \mathrm{D}(\mathrm{TN})$, Italy), and $\mathrm{N}_{2}$ adsorption-desorption isotherm tests, along with Fourier-transform infrared spectroscopy (FTIR) spectra (Perkin Elmer, spectrum 100) were utilized to explain the significant details about the structure and morphology of biochars.

\subsection{Preparation of biochars}

Both samples (cinnamon and cannabis seeds) were rinsed with deionized water several times to eliminate impurities and then dried at $25^{\circ} \mathrm{C}$ for $72 \mathrm{~h}$ and pyrolyzed at various temperatures (i.e., 300,400 , and $600^{\circ} \mathrm{C}$ ) through a tube furnace for $2 \mathrm{~h}$ under $\mathrm{N}_{2}$ atmosphere. Next, all samples were crushed via a crusher and passed by a 40 mesh sieve to obtain the primary the biochars. Additionally, $5 \mathrm{~g}$ of each sample was refluxed with 0.1 $\mathrm{M} \mathrm{HCl}$ for $12 \mathrm{~h}$, and then cooled, washed with deionized water, and dried in a vacuum oven at $80^{\circ} \mathrm{C}$. Finally, the prepared biochars at different temperatures were marked as cinnamon 300 , cinnamon 400 , cinnamon 600 , cannabis 300 , cannabis 400 , and cannabis 600 and stored in airtight plastic (Scheme 1).

\subsection{Adsorption studies}

The $\mathrm{Cd}(\mathrm{II})$ adsorption tests by various samples of biochar were conducted in a series of $50 \mathrm{~mL}$ conical flasks. Typically, $0.1 \mathrm{~g}$ of each adsorbent (i.e., cinnamon 300 , cinnamon 400 , cinnamon 600 , cannabis 300 , cannabis 400 , and cannabis 600) was added to $10 \mathrm{mLCd}$ (II) of various primary concentrations of (i.e., $60,130,180,250,350$, and $500 \mathrm{mg}$ $\mathrm{L}^{-1}$ ) and were then shaken in a thermostatic water bath shaker at $150 \mathrm{rpm}$. After $24 \mathrm{~h}$, the adsorbent samples were filtered with $0.45 \mu \mathrm{m}$ filter and the content of the remaining $\mathrm{Cd}(\mathrm{II})$ ions in the volume of the solution was evaluated 
Scheme 1 Schematic diagram for preparation of biochars
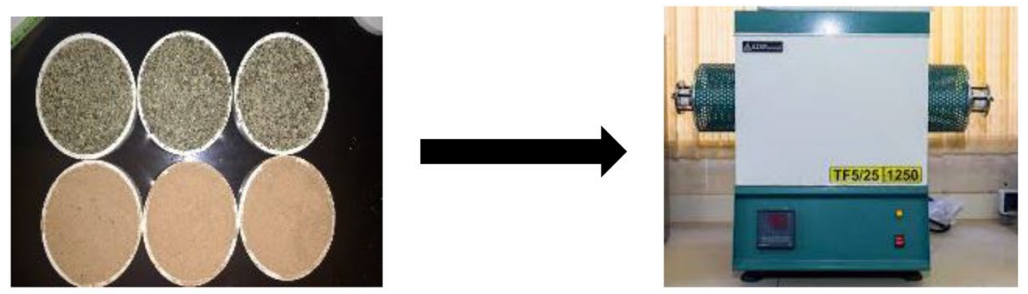

Cinnamon and cannabis
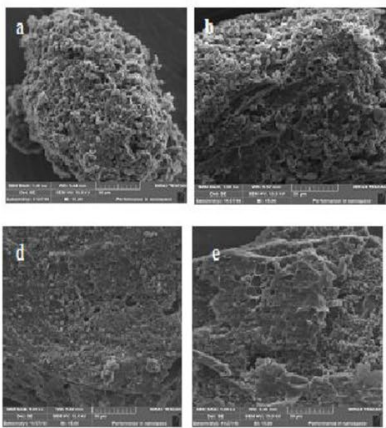

Pyrolysis
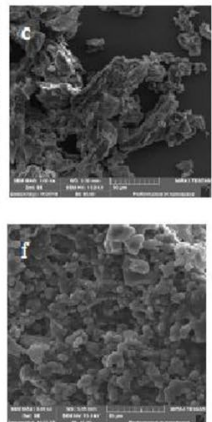
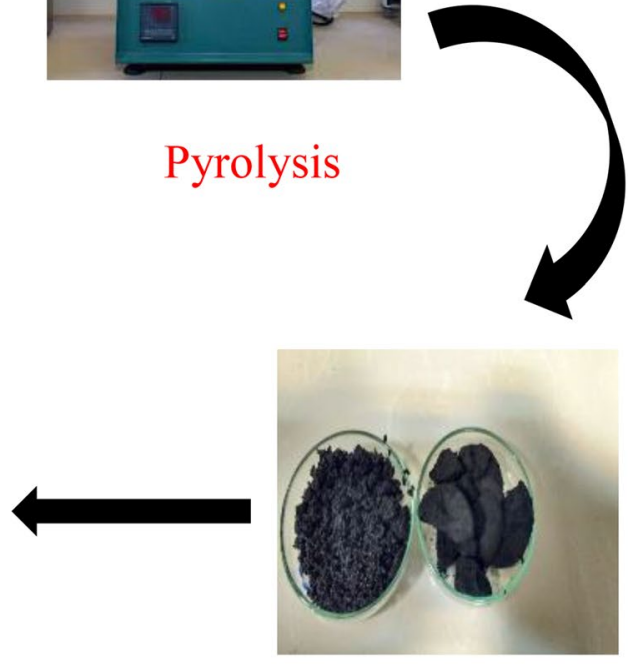

Binchar

\subsection{Effect of $\mathrm{pH}$}

ions was obtained by Eq. (1) as follows:

$\mathrm{q}_{\mathrm{e}}=\frac{\left(\mathrm{C}_{0}-\mathrm{C}_{\mathrm{e}}\right) \mathrm{V}}{\mathrm{W}}$

where $\mathrm{C}_{0}$ and $\mathrm{C}_{\mathrm{e}}\left(\mathrm{mg} \mathrm{L}^{-1}\right)$ denote the primary and ultimate contents of $\mathrm{Cd}(\mathrm{II})$ ions, respectively. In addition, $\mathrm{V}(\mathrm{L})$ and $\mathrm{W}$ (g) demonstrates the volume of standard solutions $\mathrm{Cd}$ (II) and the mass of each biochar in all tests.

\subsection{Kinetic studies}

The kinetic studies were performed at primary Cd(II) level of $60 \mathrm{mg} \mathrm{L}^{-1}$. Each $10 \mathrm{~mL}$ of Cd(II) solution containing $0.1 \mathrm{~g}$ of adsorbent (i.e., cinnamon 300 , cinnamon 400 , cinnamon 600 , cannabis 300 , cannabis 400 , and cannabis 600 ) were placed in a thermostatic water bath shaker (150 rpm), and at different time intervals, the residual levels of $\mathrm{Cd}(\mathrm{II}), \mathrm{C}_{\mathrm{t}}$ were determined by an ICP-OES analysis. The amount of $\mathrm{Cd}$ (II) ions adsorbed at each time interval per unit mass of the adsorbent $\mathrm{q}_{\mathrm{t}}\left(\mathrm{mg} \mathrm{g}^{-1}\right.$ ) was evaluated by using Eq. (2):

$q_{t}=\frac{\left(C_{0}-C_{t}\right) V}{W}$

In this equation, $C_{0}$ and $C_{t}\left(\mathrm{mg} \mathrm{L}^{-1}\right)$ are the contents of the liquid phase of $\mathrm{Cd}(\mathrm{II})$ at primary and any time $\mathrm{t}$, respectively.

The effects of $\mathrm{pH}$ in the range of 3.0 to 9.0 with a stirring time of 60 min on the removal of Cd(II) were investigated by using $0.1 \mathrm{~mol} \mathrm{~L}^{-1} \mathrm{HCl}$ or $\mathrm{NaOH}$ solutions for the initial $\mathrm{pH}$ adjustment, with the primary $\mathrm{Cd}(\mathrm{II})$ content fixed at $60 \mathrm{mg} \mathrm{L}^{-1}$.

\subsection{Effect of the amount of adsorbent}

The dependency of the adsorption of $\mathrm{Cd}(\mathrm{II})$ ions was studied by $0.04 \mathrm{~g}$ to $0.3 \mathrm{~g}$ amounts of adsorbent in contact with $10 \mathrm{~mL}$ solution of $60 \mathrm{mg} \mathrm{L}^{-1}$ of $\mathrm{Cd}$ (II) with agitation time of $60 \mathrm{~min}$.

\section{Results and discussion}

\subsection{Characterization of adsorbents}

To assess the influence of temperature on prepared biochars, the temperature values at $300-600^{\circ} \mathrm{C}$ were synthesized and their structures were characterized by various styles. The X-ray powder diffraction (XRD) patterns of cinnamon 300, cinnamon 400, and cinnamon 600 displayed the peaks at $15^{\circ}, 25^{\circ}, 29^{\circ}$, and $38^{\circ}$ correspond to the planes of (012), (102), (024), and (125) exhibiting the $\mathrm{CaC}_{2} \mathrm{O}_{4} \cdot \mathrm{H}_{2} \mathrm{O}$. For cinnamon 600 , three new peaks at around $14^{\circ}, 25^{\circ}$, and $29^{\circ}$ possibly connected with the pattern of the $\mathrm{CaCO}_{3}$ by 
comparison with Joint Committee on Powder Diffraction Standards (JCPDS Card, File No. 79-0418). Further, the XRD patterns of cannabis 300 , cannabis 400, and cannabis 600 illustrate the amorphous-crystalline of biochar. As shown, the peaks on the structure of biochars increase due to biochars crystallization by enhancing the temperature (Fig. 1).

The Fourier-transform infrared spectroscopy spectra of various biochars are displayed in Fig. 2. Based on the data, the fabricated biochars offer the broad bands at 1300 , 1900 , and $3400 \mathrm{~cm}^{-1}$, corresponding to the $\mathrm{O}-\mathrm{H}$ stretching vibration and the adsorption peak at $2900 \mathrm{~cm}^{-1}$, which is related to the aliphatic $-\mathrm{CH}_{2}$ stretching variation. The peaks occurring at 575,570 , and $567 \mathrm{~cm}^{-1}$ indicated the presence of $\mathrm{C}-\mathrm{Br}$. Furthermore, the peak at $850 \mathrm{~cm}^{-1}$ was assigned to the $\mathrm{C}-\mathrm{H}$ bond. Additionally, two bands at 1618 and $1179 \mathrm{~cm}^{-1}$ were related to the $\mathrm{N}-\mathrm{H}$ and $\mathrm{C}=\mathrm{O}$ groups, respectively. The Fourier-transform infrared spectroscopy results represented that all biochars encompassed different functional groups such as $\mathrm{O}-\mathrm{H},-\mathrm{CH}_{2}, \mathrm{C}-\mathrm{H}, \mathrm{N}-\mathrm{H}$, and $\mathrm{C}=\mathrm{O}$ on their surface, which could supply great active positions for eliminating the $\mathrm{Cd}(\mathrm{II})$ ions. Finally, the peaks reduced in high pyrolysis temperature due to the breaking bonds of the aliphatic $[18,19]$.

Figure 3 depicts the scanning electron microscopy images of cinnamon 300, cinnamon 400, cinnamon 600, cannabis 300 , cannabis 400 , and cannabis 600 . As shown, the biochars derived from cinnamon and cannabis demonstrate a porous structure and various cavities were detected on their surface when cinnamon and cannabis pyrolyzed at $600^{\circ} \mathrm{C}$.
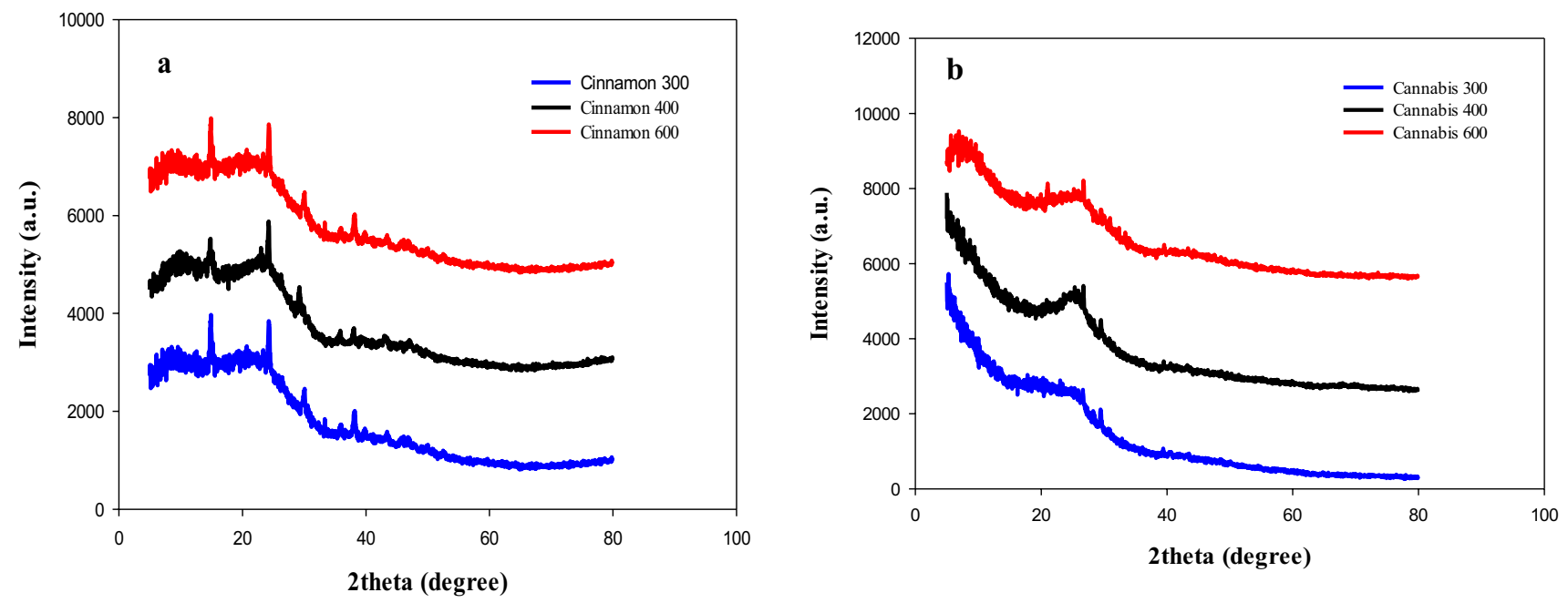

Fig. 1 XRD patterns of cinnamon 300, cinnamon 400, cinnamon 600 (a) and cannabis 300, cannabis 400, and cannabis 600 (b)
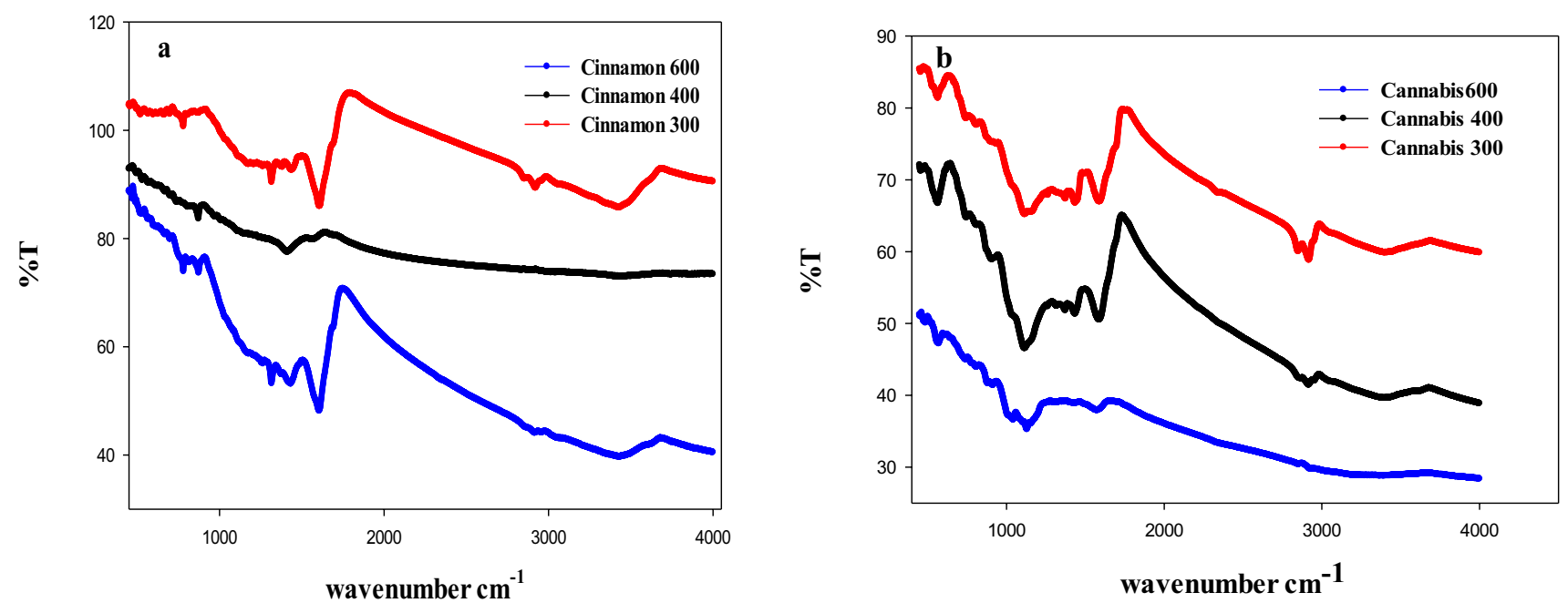

Fig. 2 FT-IR spectrum of cinnamon 300, cinnamon 400, cinnamon 600 (a) and cannabis 300, cannabis 400, and cannabis 600 (b) 

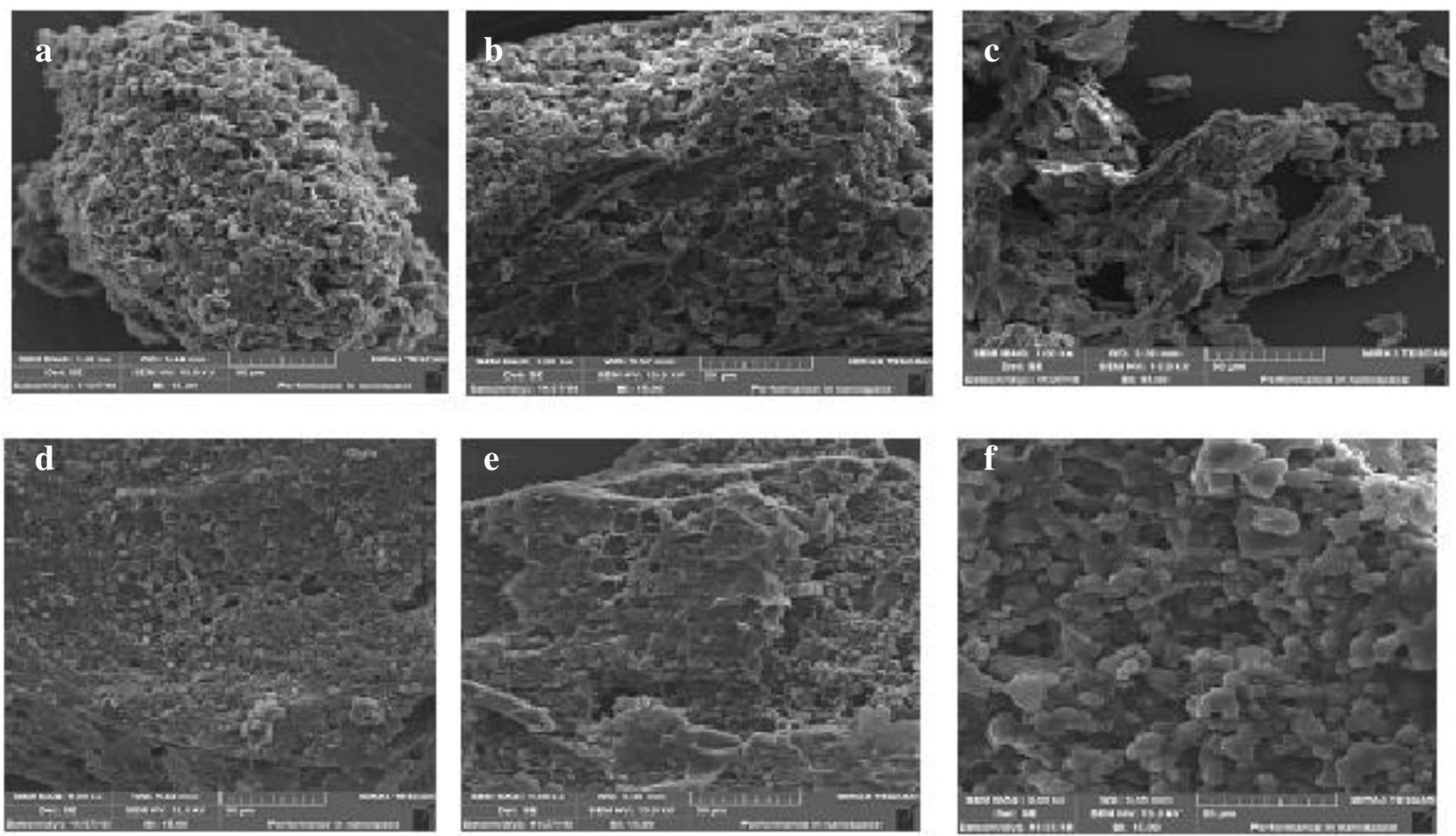

Fig. 3 SEM images of cinnamon 300 (a), cinnamon 400 (b), cinnamon 600 (c), cannabis 300 (d), cannabis 400 (e), and cannabis 600 (f)

The porosity and surface area of cinnamon 300 , cinnamon 400 , cinnamon 600 , cannabis 300 , cannabis 400 , and cannabis 600 were tested by $\mathrm{N}_{2}$ adsorption-desorption isotherms (Fig. 4). Based on the results, cinnamon 300, cinnamon 400 , cinnamon 600 , cannabis 300 , cannabis 400 , and cannabis 600 have a specific surface area of 0.64745 , $0.66238 \mathrm{~m}, 0.67918,1.1516,1.2330$, and $2.8903 \mathrm{~m}^{2} \mathrm{~g}^{-1}$, as well as an average pore size diameter of $34.039,21.501$, $22.816,0.3523,108.27$, and $29.350 \mathrm{~nm}$, respectively. It was also found out that the nitrogen isotherms for all of the adsorbents are belonged to type IV according to the classification of I.U.P.A.C. In the present study, the $S_{B E T}$ of prepared adsorbents by the pyrolysis method increased by increasing the temperature from 300 to $600^{\circ} \mathrm{C}$, which supplied different adsorption positions for $\mathrm{Cd}$ ions. Eventually, the results revealed that hydrochloric acid cannot destruct the porous structure of the adsorbents.

\subsection{Influence of $\mathrm{pH}$}

The $\mathrm{pH}$ of the wastewater solution influences both the presence of $\mathrm{Cd}(\mathrm{II})$ ions and the charge attributes of the biochars. The primary $\mathrm{pH}$ of $\mathrm{Cd}$ (II) solution was selected in the range of 3.0-9.0 in order to evaluate the influence by the $\mathrm{pH}$. Figure 5 indicates that the adsorption percentage of $\mathrm{Cd}(\mathrm{II})$ ions gradually enhances as the $\mathrm{pH}$ of the primary solution of $\mathrm{Cd}(\mathrm{II})$ increases from 3.0 to 7.0. Based on the results, the maximum adsorption efficiency of 95 , $96.5,98.8,95,95.5$, and $97.3 \%$ was obtained for cinnamon 300 , cinnamon 400 , cinnamon 600 , cannabis 300 , cannabis 400 , and cannabis 600 , respectively, when the $\mathrm{pH}$ level was equal to 7.0. Under acidic $\mathrm{pH}(\mathrm{pH}<7.0)$, various groups in the biochars are simply protonated, leading to electrostatic repulsion of $\mathrm{Cd}$ (II) ions. On the other hand, adsorption efficiency increases due to the deprotonation of the surface groups of cinnamon 300 , cinnamon 400 , cinnamon 600 , cannabis 300 , cannabis 400 , and cannabis 600 under alkaline $\mathrm{pH}(\mathrm{pH}>7.0)$. At the $\mathrm{pH}$ of 8.0 and 9.0, the $\mathrm{Cd}(\mathrm{II})$ adsorption represented no remarkable change due to electrostatic reaction. In addition, the effect of solution $\mathrm{pH}$ on $\mathrm{Cd}(\mathrm{II})$ adsorption by each biochar can be well described in terms of the $\mathrm{pH}$ point of zero charges $\left(\mathrm{pH}_{\mathrm{PZC}}\right)$ of the adsorbents [20]. The $\mathrm{pH}_{\mathrm{PZC}}$ of the cinnamon 300 , cinnamon 400 , cinnamon 600 , cannabis 300 , cannabis 400 , and cannabis 600 were found 5.0 and were the same for all these adsorbents. In general, the surface charge of cinnamon 300 , cinnamon 400 , cinnamon 600 , cannabis 300 , cannabis 400 , and cannabis 600 is positive when $\mathrm{pH}<5.0$ while that of cinnamon 300 , cinnamon 400 , cinnamon 600 , cannabis 300 , cannabis 400 , and cannabis 600 is negative when $\mathrm{pH}>5.0$, making the situation desirable for $\mathrm{Cd}(\mathrm{II})$ ion adsorption.

Further, the $\mathrm{pH}$ variation was associated with $\mathrm{Cd}(\mathrm{II})$ species that were present in several forms in solutions 

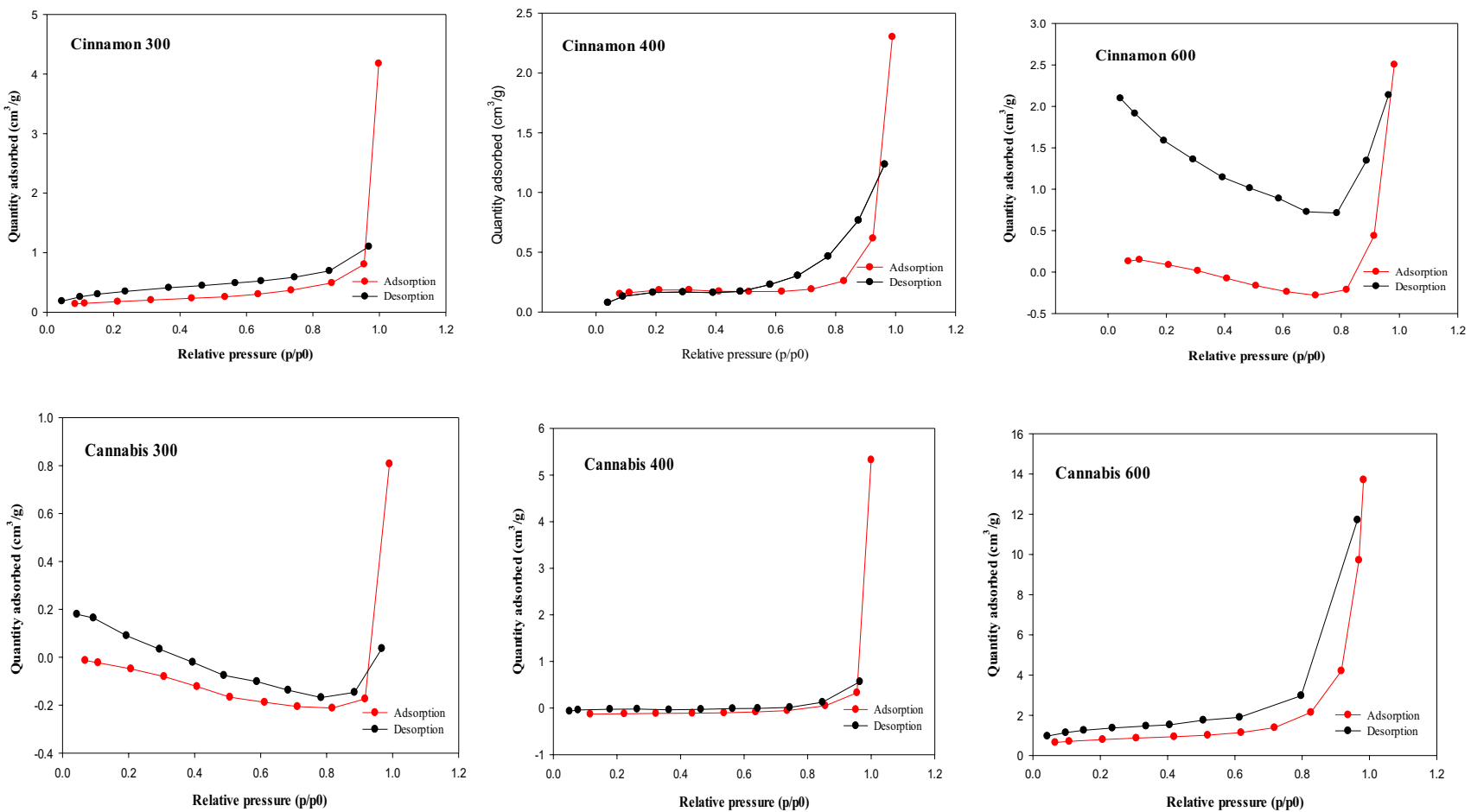

Fig. 4 Nitrogen adsorption-desorption isotherm for cinnamon 300, cinnamon 400, cinnamon 600, cannabis 300, cannabis 400, and cannabis 600
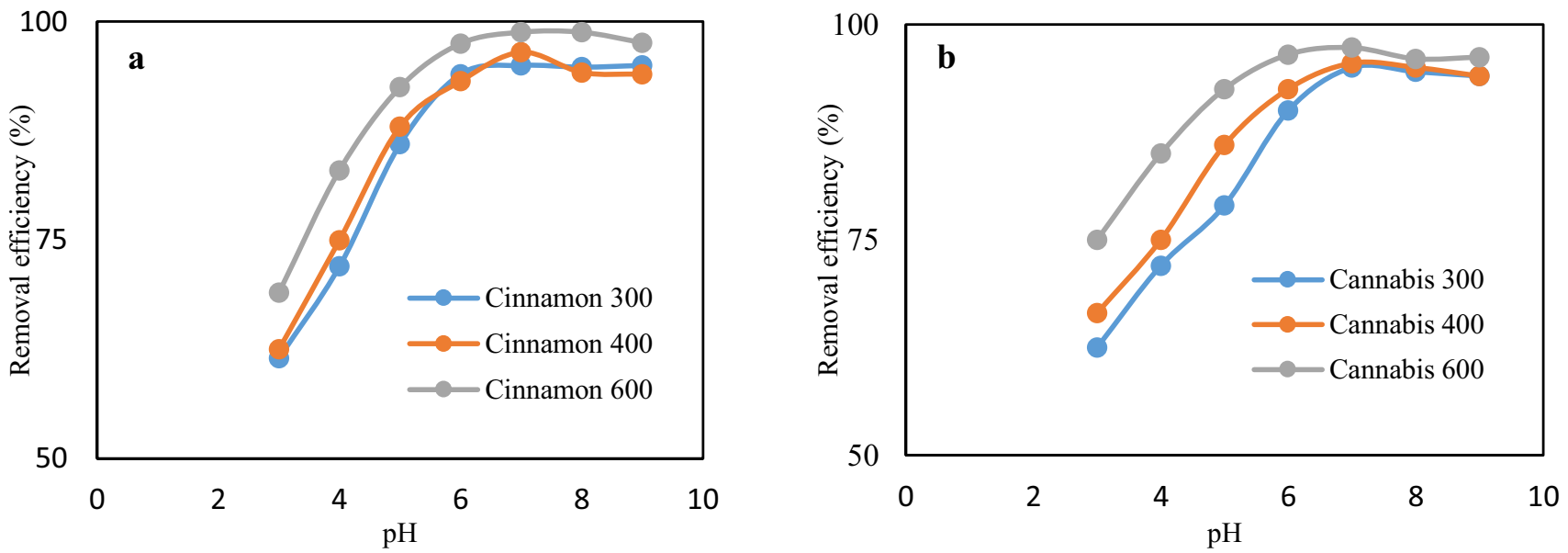

Fig. 5 Influence of solution $\mathrm{pH}$ on the removal percentage of $\mathrm{Cd}(\mathrm{II})$ ions by cinnamon 300 , cinnamon 400 , cinnamon 600 (a) and cannabis 300 , cannabis 400 , and cannabis $600(\mathbf{b})\left(C_{0}=60 \mathrm{mg} \mathrm{L}^{-1}\right.$, adsorbent dose $=0.1 \mathrm{~g}$, contact time $=60 \mathrm{~min}$, and temperature $\left.=65^{\circ} \mathrm{C}\right)$

such as $\mathrm{Cd}(\mathrm{OH})^{+}, \mathrm{Cd}(\mathrm{OH})_{2}, \mathrm{Cd}(\mathrm{OH})_{4}^{2-}$, and $\mathrm{Cd}(\mathrm{OH})^{3-} \mathrm{Cd}$ ${ }^{2+}$. Therefore, $\mathrm{Cd}(\mathrm{II})$ ions were adsorbed in $\mathrm{pH}=7.0$ due to electrostatic attractions between $\mathrm{Cd}^{2+}$ and the negative charge of cinnamon 300, cinnamon 400, cinnamon 600, cannabis 300 , cannabis 400 , and cannabis 600 . In the $\mathrm{pH}$ of above 9.0, the elimination of $\mathrm{Cd}(\mathrm{II})$ ions occurred due to the precipitation of $\mathrm{Cd}(\mathrm{OH})_{2}$ and $\mathrm{Cd}(\mathrm{OH})^{+}$. A similar behavior has been reported for $\mathrm{Cd}(\mathrm{II})$ ion adsorption on
SDS-coated magnetite nanoparticles modified with 2,4DNPH [9].

\subsection{Influence of adsorbent dose}

Figure 6 depicts the effect of different amounts (0.04-0.3 g) of cinnamon 300 , cinnamon 400 , cinnamon 600 , cannabis 300 , cannabis 400 , and cannabis 600 on the 

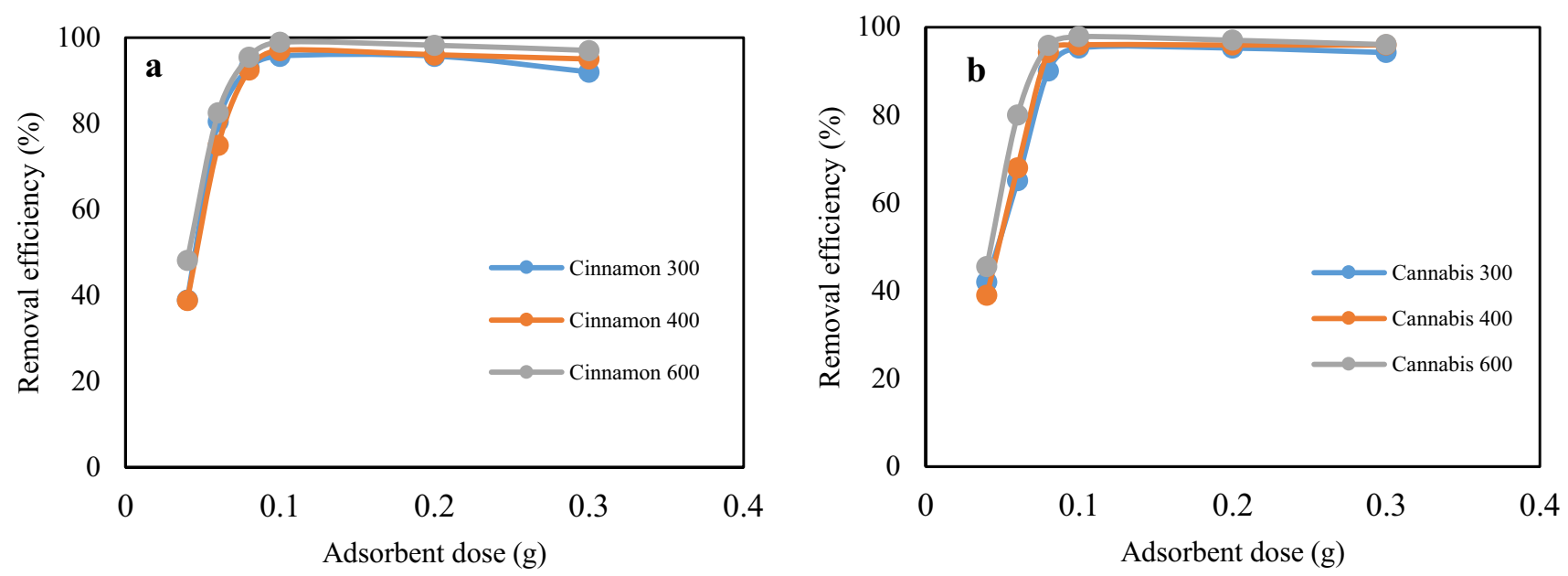

Fig. 6 Influence of adsorbent dose on the removal percentage of Cd(II) ions by cinnamon 300, cinnamon 400, cinnamon 600 (a) and cannabis 300 , cannabis 400 , and cannabis $600(\mathrm{~b})\left(\mathrm{pH}=7.0, \mathrm{C}_{0}=60 \mathrm{mg} \mathrm{L}^{-1}\right.$, contact time $=60 \mathrm{~min}$, and temperature $\left.=65^{\circ} \mathrm{C}\right)$

adsorption of $\mathrm{Cd}$ (II) ions for primary $\mathrm{Cd}$ (II) concentration of $60 \mathrm{mg} \mathrm{L}^{-1}$. As expected, the Cd(II) ions were gradually eliminated by adding the amount of biochars from 0.04 to $0.1 \mathrm{~g}$ and remained constant in $0.1 \mathrm{~g}$ with the maximum percent of $95.7,97.0,98.9,95.26,95.9$, and $97.8 \%$ for cinnamon 300 , cinnamon 400 , cinnamon 600 , cannabis 300 , cannabis 400 , and cannabis 600 , respectively. In the first step, a fast increase was observed in elimination percentage, denoting that this observation can be explained via increase in the surface area and availability of more active sites for adsorption. Afterward (from 0.1 g), it becomes fairly constant for any further increase in the adsorbent dose because of the limitation $\mathrm{Cd}$ (II) ions as compared with the biochars sites available for the reaction. These results are in agreement with those reported in the literature [21].

\subsection{Influence of temperature}

The impact of solution temperature on the adsorption process of $\mathrm{Cd}(\mathrm{II})$ ions by the obtained biochars from cinnamon and cannabis was analyzed through altering the reaction temperature in the range of $25-65^{\circ} \mathrm{C}$ in the similar testable situation (Fig. 7). Based on the results, the elimination percentage of $\mathrm{Cd}(\mathrm{II})$ ions increased from 35 to $95,37.5$ to $96,45.5$ to $97.5,48.2$ to $90.9,46.4$ to $93 \%$, and 52 to $96.8 \%$ for cinnamon 300 , cinnamon 400 , cinnamon 600 , cannabis 300 , cannabis 400 , and cannabis 600 , respectively, when the process temperature increased from 25 to $65^{\circ} \mathrm{C}$. This demonstrated that the $\mathrm{Cd}$ (II) ion adsorption was the endothermic operation and expanding temperature encouraged adsorption procedure and temperature $65^{\circ} \mathrm{C}$ was appropriate to the spontaneous reaction. Similar results
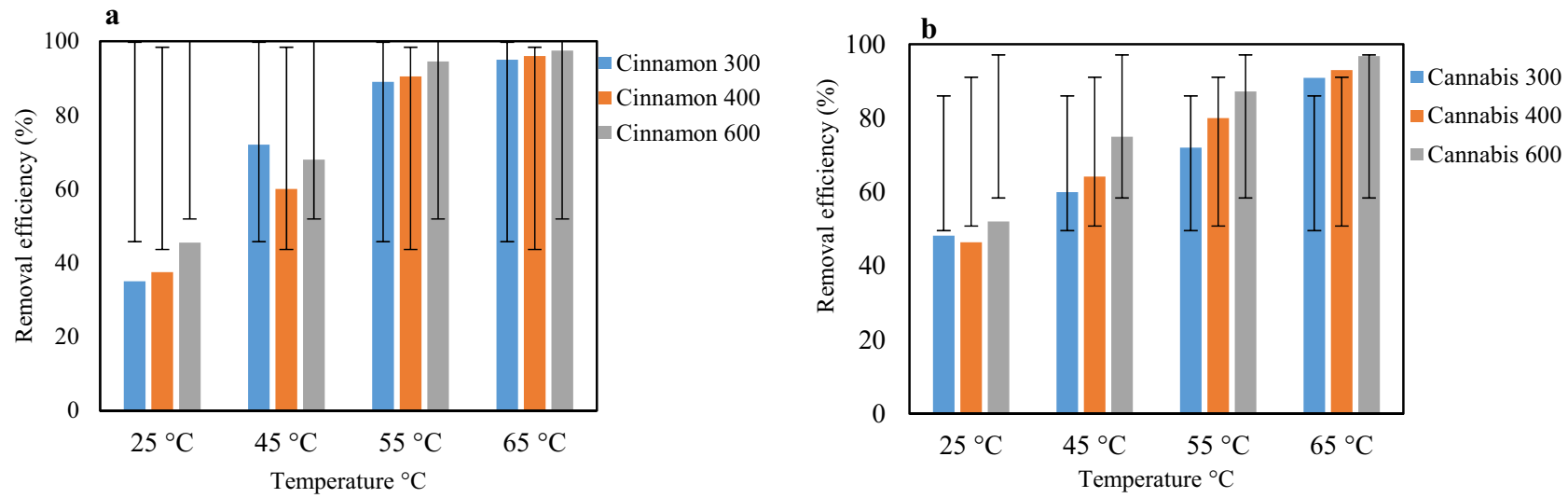

Fig. 7 Influence of temperature with Standard deviation(s) on the removal percentage of Cd(II) ions by cinnamon 300, cinnamon 400 , cinnamon 600 (a) and cannabis 300, cannabis 400, and cannabis 600 (b) $\left(\mathrm{pH}=7.0, \mathrm{C}_{0}=60 \mathrm{mg} \mathrm{L}^{-1}\right.$, adsorbent dose $=0.1 \mathrm{~g}$, contact time $\left.=60 \mathrm{~min}\right)$ 
for the metal ions adsorption at various temperature on $\mathrm{Fe}_{2} \mathrm{O}_{3} @ \mathrm{SiO}_{2}$ thin films have also been reported [8].

\subsection{Influence of ionic strength}

The effect of ionic strength on $\mathrm{Cd}(\mathrm{II})$ ions adsorption onto cinnamon 300 , cinnamon 400 , cinnamon 600 , cannabis 300 , cannabis 400 , and cannabis 600 was studied using changing concentrations between 0.0 and 0.5 M..Fig. 7 shows the effect of ionic strength $\left(\mathrm{K}^{+}\right.$and $\left.\mathrm{Na}^{+}\right)$on the adsorption of $\mathrm{Cd}$ (II) ions. As shown in Fig. 8, the adsorption percentage of $\mathrm{Cd}(\mathrm{II})$ ions decreased with increase of ionic strength at all concentrations. This decrease in the $\mathrm{Cd}(\mathrm{II})$ elimination may be due to the competition between $\mathrm{Cd}(\mathrm{II})$ ions and $\mathrm{K}^{+}$and $\mathrm{Na}^{+}$for adsorption sites.

\subsection{Influence of primary Cd(II) concentration and equilibrium studies}

The primary $\mathrm{Cd}(\mathrm{II})$ concentration on the adsorption operation of $\mathrm{Cd}(\mathrm{II})$ ions via cinnamon 300 , cinnamon 400 , cinnamon 600 , cannabis 300 , cannabis 400 , and cannabis 600
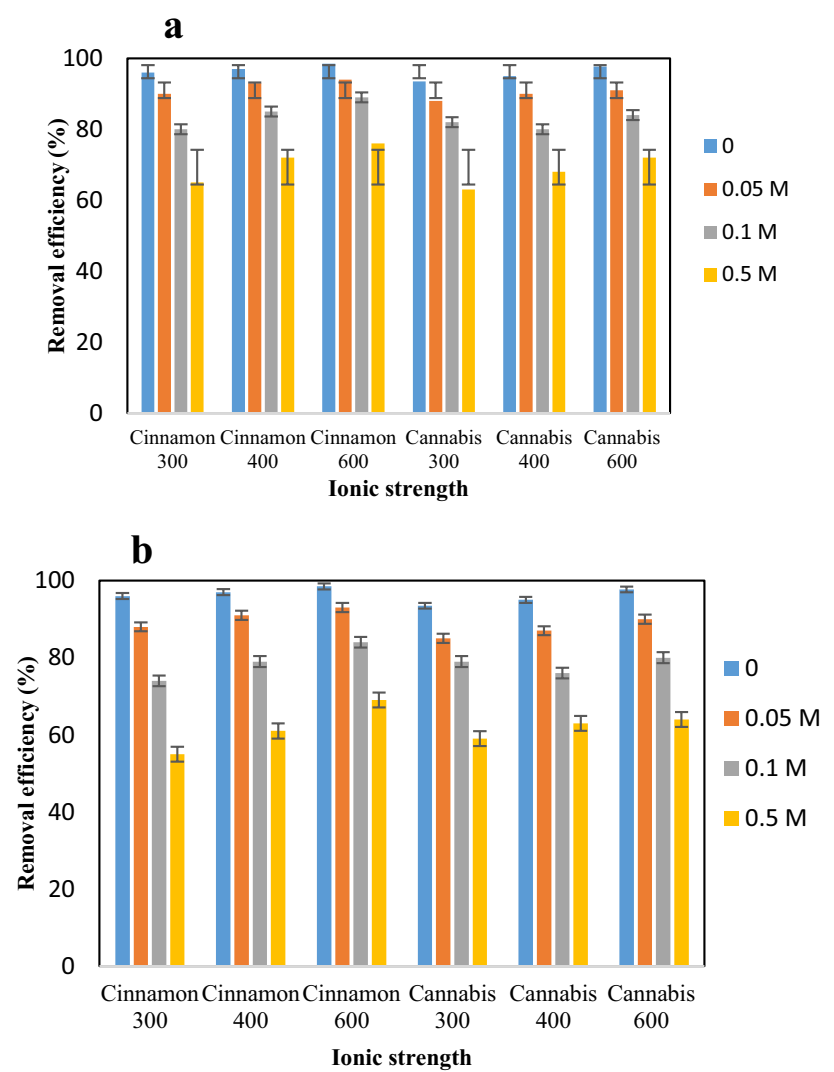

Fig. 8 Influence of ionic strength $\left(\mathrm{Na}^{+}\right.$(a) and $\left.\mathrm{K}^{+}(\mathbf{b})\right)$ on the removal percentage of $\mathrm{Cd}(\mathrm{II})$ ions by cinnamon 300 , cinnamon 400 , cinnamon 600 (a) and cannabis 300, cannabis 400, and cannabis 600 was checked for the primary concentrations of 60 to 500 $\mathrm{mg} \mathrm{L}^{-1}$ as the amount of each biochar was constant. The results explain that the elimination efficiency of $\mathrm{Cd}(\mathrm{II})$ ions reduced from 92 to 54,93 to $55,98.5$ to 60,87 to 47,89 to 51 , and 95 to $64 \%$ for cinnamon 300 , cinnamon 400, cinnamon 600 , cannabis 300 , cannabis 400 , and cannabis 600 , respectively, by an increase in the primary concentration from 60 to $500 \mathrm{mg} \mathrm{L}^{-1}$. However, the adsorption ability $\left(\mathrm{q}_{\mathrm{e}}\right)$ of $\mathrm{Cd}(\mathrm{II})$ ions by cinnamon 300 , cinnamon 400 , cinnamon 600 , cannabis 300 , cannabis 400 , and cannabis 600 regularly increased by adding the primary $\mathrm{Cd}$ (II) concentration. These outcomes of adsorption can be interpreted by the surface areas of cinnamon 300 , cinnamon 400 , cinnamon 600 , cannabis 300 , cannabis 400 , and cannabis 600 . This is attributed to the presence of great empty positions at the $\mathrm{Cd}$ (II) concentration of $60 \mathrm{mgL}^{-1}$ due to a growth in the concentration slop and rate of $\mathrm{Cd}$ (II) diffusion to cinnamon 300 , cinnamon 400 , cinnamon 600 , cannabis 300 , cannabis 400 , and cannabis 600 .

By utilizing the adsorption isotherm models, the adsorption ability of cinnamon 300 , cinnamon 400 , cinnamon 600 , cannabis 300 , cannabis 400 , and cannabis 600 was studied for $\mathrm{Cd}(\mathrm{II})$ ion adsorption in the adsorbent dose of $0.1 \mathrm{~g}$ and the $\mathrm{pH}$ of 7.0 while the primary $\mathrm{Cd}(\mathrm{II})$ ion concentration altered from 60 to $500 \mathrm{mg} \mathrm{L}^{-1}$. Accordingly, the linear shape of Langmuir (L), Freundlich $(\mathrm{F})$, Temkin ( $\mathrm{T})$, and Redlich-Peterson (R-P) models was employed and revealed as follows [22-25]:

$\frac{C_{e}}{q_{e}}=\frac{C_{e}}{q_{m}}+\frac{1}{q_{m} b_{1}}$

$\mathrm{nq}_{\mathrm{e}}=\frac{1}{\mathrm{n}} \ln C_{\mathrm{e}}+\ln \mathrm{k}_{\mathrm{F}}$

$\mathrm{q}_{\mathrm{e}}=\mathrm{Blnk}_{\mathrm{t}}+\mathrm{BlnC}_{\mathrm{e}}$

$\ln \left(\mathrm{q}_{\mathrm{R}-\mathrm{P}} \mathrm{K}_{\mathrm{R}-\mathrm{P}} \frac{\mathrm{C}_{\mathrm{e}}}{\mathrm{q}_{\mathrm{e}}}-1\right)=\ln \mathrm{K}_{\mathrm{R}-\mathrm{P}}+\beta \ln \mathrm{C}_{\mathrm{e}}$

where qe and qm $\left(\mathrm{mg} \mathrm{g}^{-1}\right)$ describe the amount of adsorbed Cd(II) ions onto cinnamon 300, cinnamon 400, cinnamon 600 , cannabis 300 , cannabis 400 , and cannabis 600 in an equilibrium situation and a maximum level, respectively, in a single layer form. Both $\mathrm{k}_{\mathrm{f}}$ and $\mathrm{n}$ are assumed as the unchanging factors of $F$ and heterogeneity of biochar surface, respectively. Furthermore, the $\mathrm{K}_{\mathrm{t}} \mathrm{L}$ $\left.\mathrm{mg}^{-1}\right)$ and $B$ are related to the equilibrium binding factor and heat of adsorption, respectively. Finally, the $k_{R-P}(L$ $\mathrm{g}^{-1}$ ) and $\beta$ denote the fixed factors of the R-P model.

The parameters of the fitting models such as $L, F, T$, and $R-P$, as well as their correlation coefficients $\left(R^{2}\right)$ are 
shown in Fig. 9 and Table 1. The correlation coefficients $\left(\mathrm{R}^{2}\right)$ obtained from the $\mathrm{L}$ model for $\mathrm{Cd}(\mathrm{II})$ adsorption were $0.9989,0.9924,0.9908,0.9942,0.9890$, and 0.9935 for cinnamon 300 , cinnamon 400 , cinnamon 600 , cannabis 300 , cannabis 400 , and cannabis 600 , respectively, which were higher $\left(R^{2}>0.98\right)$ than those of $L, F$, and R-P models. Additionally, the values of $R_{L}$ were computed to be 0.245 , $0.301,0.189,0.364,0.395$, and 0.255 for cinnamon 300 , cinnamon 400 , cinnamon 600 , cannabis 300 , cannabis 400 , and cannabis 600 , respectively, representing that the $\mathrm{Cd}$ (II) adsorption onto the above-mentioned adsorbents was appropriate and the dependence between $\mathrm{Cd}(\mathrm{II})$ ions and biochars was strong.

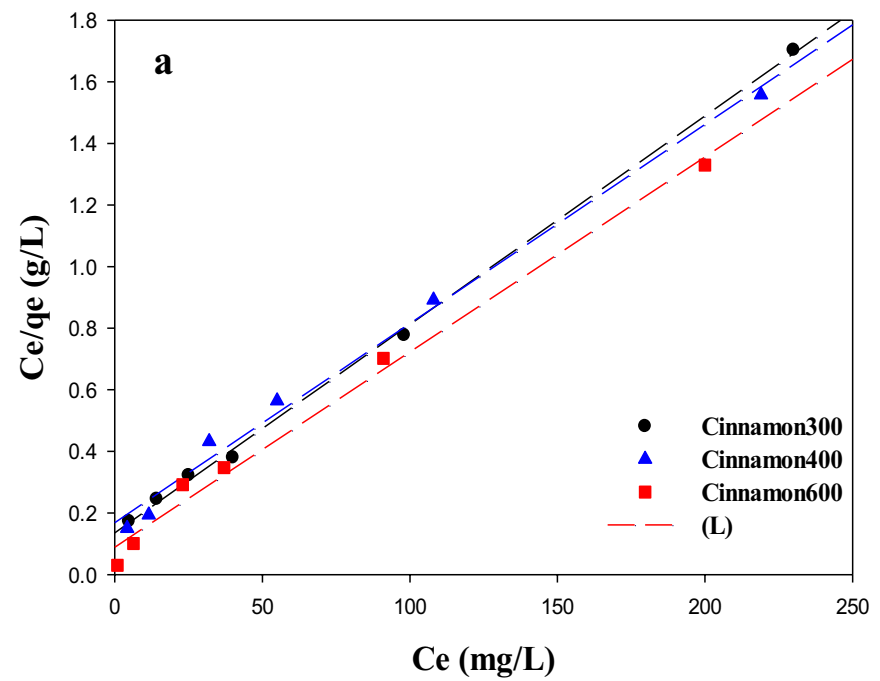

These results imply that the adsorption of $\mathrm{Cd}(\mathrm{II})$ ions onto all biochars follow the $L$ model and adsorption operation led to the homogeneous surface of cinnamon 300, cinnamon 400 , cinnamon 600 , cannabis 300 , cannabis 400 , and cannabis 600 and the monolayer adsorption of $\mathrm{Cd}(\mathrm{II})$ ions accomplished on biochars with a finite number of identical sites, that all sites are energetically equivalent, and that there is no interaction between the adsorbed molecules.

The obtained $\mathrm{q}_{\max }$ values for cinnamon 300 , cinnamon 400 , cinnamon 600 , cannabis 300 , cannabis 400 , and cannabis 600 were 147.05, 153.84, 158.73, 133.33, 144.92, and $175.43 \mathrm{mg} \mathrm{g}^{-1}$, respectively. In addition, the $\mathrm{q}_{\max }$ quantities

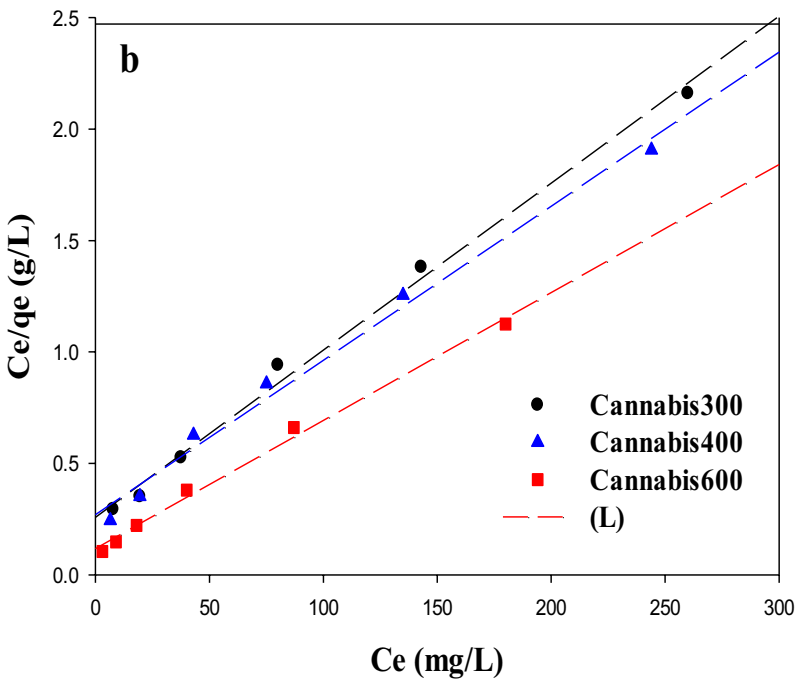

Fig. 9 The $L$ model for the adsorption of $C d(I I)$ ions onto cinnamon 300, cinnamon 400, cinnamon 600 (a) and cannabis 300, cannabis 400 , cannabis 600 (b)

Table 1 Obtained parameters for adsorption of $\mathrm{Cd}(\mathrm{II})$ ions onto cinnamon 300 , cinnamon 400 , cinnamon 600 , cannabis 300 , cannabis 400 , and cannabis 600

\begin{tabular}{|c|c|c|c|c|c|c|c|}
\hline Isotherm & Parameters & Cinnamon 300 & Cinnamon 400 & Cinnamon 600 & Cannabis 300 & Cannabis 400 & Cannabis 600 \\
\hline \multirow[t]{4}{*}{$\mathrm{L}$} & $\mathrm{q}_{\mathrm{m}}\left(\mathrm{mg} \mathrm{g}^{-1}\right)$ & 147.05 & 153.84 & 158.73 & 133.33 & 144.92 & 175.43 \\
\hline & $\mathrm{b}\left(\mathrm{L} \mathrm{mg}^{-1}\right)$ & 0.0513 & 0.0386 & 0.0711 & 0.029 & 0.0255 & 0.0485 \\
\hline & $\mathrm{R}_{\mathrm{L}}$ & 0.2451 & 0.3015 & 0.1898 & 0.3641 & 0.3957 & 0.2552 \\
\hline & $\mathrm{R}^{2}$ & 0.9989 & 0.9924 & 0.9908 & 0.9942 & 0.9890 & 0.9935 \\
\hline \multirow[t]{3}{*}{$\mathrm{F}$} & $\mathrm{K}_{\mathrm{F}}\left(\mathrm{L} \mathrm{mg}^{(1-(1 / \mathrm{n}))} \mathrm{g}^{-1}\right)$ & 15.50 & 18.757 & 32.505 & 14.049 & 13.668 & 21.977 \\
\hline & $\mathrm{n}$ & 2.131 & 2.537 & 3.312 & 2.464 & 2.373 & 2.468 \\
\hline & $\mathrm{R}^{2}$ & 0.9466 & 0.9533 & 0.9599 & 0.9296 & 0.9721 & 0.9556 \\
\hline \multirow[t]{3}{*}{$\mathrm{T}$} & B & 33.245 & 28.225 & 22.446 & 25.497 & 27.523 & 31.952 \\
\hline & $\mathrm{K}_{\mathrm{T}}\left(\mathrm{L} \mathrm{mg}^{-1}\right)$ & 2.189 & 1.646 & 2.947 & 2.399 & 2.775 & 1.241 \\
\hline & $\mathrm{R}^{2}$ & 0.9875 & 0.9845 & 0.9599 & 0.9867 & 0.9860 & 0.9871 \\
\hline \multirow[t]{4}{*}{ R-P } & $q_{R-P}$ & 254.2 & 276.1 & 300.02 & 192.21 & 210.52 & 245.37 \\
\hline & $K_{R-P}$ & 0.2151 & 0.124 & 0.152 & 0.224 & 0.218 & 0.291 \\
\hline & $\beta$ & 1.021 & 0.985 & 0.971 & 1.152 & 1.126 & 1.075 \\
\hline & $\mathrm{R}^{2}$ & 0.990 & 0.9872 & 0.9889 & 0.9851 & 0.9760 & 0.9912 \\
\hline
\end{tabular}


were in the order of cannabis $600>$ cinnamon $600>$ cinnamon 400 > cinnamon 300 > cannabis $400>$ cannabis 300 , indicating that temperature plays an overcoming role on the structure of biochars. In other words, the produced biochars at a higher temperature (i.e., cinnamon 600 and cannabis 600) had more active sites and specific surface area compared to the other biochars. Further, the obtained $\mathrm{q}_{\max }$ values from cinnamon 600 and cannabis 600 for $\mathrm{Cd}(\mathrm{II})$ ions were significantly larger than those formerly introduced in the literature for the elimination of $\mathrm{Cd}(\mathrm{II})$ ions using different adsorbents (Table 2).

\subsection{Influence of equilibrium time and kinetic studies}

The tests were completed at various times of $0-80 \mathrm{~min}$ with $0.1 \mathrm{~g}$ from each adsorbent and the primary $\mathrm{Cd}$ (II) concentration of $60 \mathrm{mg} \mathrm{L}^{-1}$ in order to observe the influence of adsorption activity time on the removal efficiency and ability of cinnamon 300, cinnamon 400, cinnamon 600 , cannabis 300 , cannabis 400 , and cannabis 600 . The results revealed that the elimination rate of $\mathrm{Cd}(\mathrm{II})$ ions via cinnamon 300 , cinnamon 400 , cinnamon 600 , cannabis 300 , cannabis 400 , and cannabis 600 was extraordinary at the outset, probably given that more adsorption positions were present at the primary phase compared to the following phases. Thus, the $\mathrm{Cd}(\mathrm{II})$ ions can connect comfortably with these places. However, $\mathrm{Cd}$ (II) elimination by all biochars reduced over time and most active positions on the surface of cinnamon 300, cinnamon 400 , cinnamon 600 , cannabis 300 , cannabis 400 , and cannabis 600 were occupied by these ions and the adsorption rate of $\mathrm{Cd}$ (II) diminished as well. In general, the quantity of the adsorbed $\mathrm{Cd}(\mathrm{II})$ ions enhanced by increasing the reaction time and peaked after $60 \mathrm{~min}$. The reaction time of $60 \mathrm{~min}$ was adequate for achieving the adsorption equilibrium for all synthesized biochars at various temperatures.

To understand managing adsorption procedure between adsorbents (i.e., cinnamon 300, cinnamon 400 , cinnamon 600 , cannabis 300 , cannabis 400 , and cannabis $600)$ and $\mathrm{Cd}(\mathrm{II})$ ions, four kinetic models containing the pseudo-first-order (PFO), pseudo-second-order (PSO), Elovich (E), and the intraparticle diffusion (ID) were utilized to analyze the empirical data. Equations (7)-(10) represent the linear relations of the four models $[32,33]$.

$\log \left(q_{e}-q_{t}\right)=\log \left(q_{e}\right)-\frac{k_{1} t}{2.303}$

$\frac{t}{q_{t}}=\frac{1}{k_{2} q_{e}^{2}}+\frac{t}{q_{e}}$

$\mathrm{q}_{\mathrm{t}}=\frac{1}{\beta} \ln (\alpha \beta)+\frac{1}{\beta} \ln (\mathrm{t})$

$\mathrm{q}_{\mathrm{t}}=\mathrm{k}_{\mathrm{ID}} \mathrm{t}^{0.5}+\mathrm{A}$

where qe and $\mathrm{qt}\left(\mathrm{mg} \mathrm{g}^{-1}\right)$ indicate the ability of each biochar for $\mathrm{Cd}(\mathrm{II})$ ion adsorption at equilibrium time and any time $\mathrm{t}(\mathrm{min})$, respectively, and $\mathrm{k}_{1}\left(\mathrm{~min}^{-1}\right)$ and $\mathrm{k}_{2}\left(\mathrm{mg} \mathrm{g}^{-1}\right.$ $\mathrm{min}^{-1}$ ) denote PFO and PSO rate fixed factors, respectively. In addition, $\mathrm{KID}$ and $\mathrm{A}\left(\mathrm{mg} \mathrm{g}^{-1}\right)$ are considered as the ID unchanging factors and $\alpha$ and $\beta$ represent the $E$ constant parameters.

The quantities of the kinetic parameters of four linear models (i.e., PFO, PSO, E, and ID) are shown in Table 3
Table 2 Comparison of $\mathrm{q}_{\mathrm{m}}$ of different adsorbents for adsorption of $\mathrm{Cd}(\mathrm{II})$ ions

\begin{tabular}{lcl}
\hline Adsorbent & $\mathrm{q}_{\mathrm{m}}\left(\mathrm{mg} \mathrm{g}^{-1}\right)$ & References \\
\hline Pristine biochar & 30.58 & {$[26]$} \\
Fe-Mn binary oxide-biochar & 95.23 & {$[26]$} \\
Corn stalk & 40.0 & {$[27]$} \\
Iminodiacetic acid-modified magnetic biochar & 197.9 & {$[28]$} \\
Imprinted polymers & 107.0 & {$[29]$} \\
Amino modification of rice straw-derived biochar & 72.1 & {$[5]$} \\
P. semisulcatuse chitin & 19.15 & {$[7]$} \\
Mercapto-modified coal gangue & 110.4 & {$[30]$} \\
Callinectes sapidus biomass & 29.23 & {$[31]$} \\
Cinnamon 300 & 147.05 & In this study \\
Cinnamon 400 & 153.84 & In this study \\
Cinnamon 600 & 158.73 & In this study \\
Cannabis 300 & 133.33 & In this study \\
Cannabis 400 & 144.92 & In this study \\
Cannabis 600 & 175.43 & In this study \\
\hline
\end{tabular}


Table 3 Constant of kinetic models for adsorption of $\mathrm{Cd}(\mathrm{II})$ ions onto cinnamon 300, cinnamon 400, cinnamon 600, cannabis 300 , cannabis 400 , and cannabis 600

\begin{tabular}{|c|c|c|c|c|c|c|c|}
\hline \multirow[t]{2}{*}{ Isotherm } & \multirow[t]{2}{*}{ Parameters } & \multicolumn{6}{|l|}{$\mathrm{Cd}(\mathrm{II})$ ions } \\
\hline & & $\begin{array}{l}\text { Cinnamon } \\
300\end{array}$ & $\begin{array}{l}\text { Cinnamon } \\
400\end{array}$ & Cinnamon 600 & Cannabis 300 & Cannabis 400 & Cannabis 600 \\
\hline \multirow[t]{3}{*}{ PFO } & $\mathrm{k}_{1}\left(\mathrm{~min}^{-1}\right)$ & 0.0415 & 0.0497 & 0.0617 & 0.0551 & 0.0372 & 0.0338 \\
\hline & $\mathrm{q}_{\mathrm{e}}\left(\mathrm{mg} \mathrm{g}^{-1}\right)$ & 16.36 & 18.04 & 19.321 & 10.797 & 11.438 & 9.369 \\
\hline & $\mathrm{R}^{2}$ & 0.9546 & 0.9227 & 0.9546 & 0.9220 & 0.7896 & 0.8175 \\
\hline \multirow[t]{3}{*}{ PSO } & $\mathrm{k}_{2}\left(\mathrm{~g} \mathrm{mg}^{-1} \min \right)$ & 0.0031 & 0.0035 & 0.0042 & 0.0088 & 0.0048 & 0.0067 \\
\hline & $\mathrm{q}_{\mathrm{e}}\left(\mathrm{mg} \mathrm{g}^{-1}\right)$ & 32.57 & 32.15 & 32.78 & 29.41 & 31.54 & 31.152 \\
\hline & $\mathrm{R}^{2}$ & 0.9988 & 0.9984 & 0.9987 & 0.9998 & 0.9983 & 0.9994 \\
\hline \multirow[t]{3}{*}{$\mathrm{E}$} & $a$ & 10.46 & 9.643 & 14.540 & 71.97 & 17.823 & 57.33 \\
\hline & $\beta$ & 0.169 & 0.162 & 0.1705 & 0.250 & 0.185 & 0.2311 \\
\hline & $\mathrm{R}^{2}$ & 0.9801 & 0.9788 & 0.9642 & 0.9180 & 0.9507 & 0.9782 \\
\hline \multirow[t]{3}{*}{ ID } & $\mathrm{K}_{\mathrm{ID}}\left(\mathrm{mg} \mathrm{g}^{-1} \min ^{1 / 2}\right)$ & 2.230 & 2.276 & 2.173 & 1.457 & 2.009 & 1.6329 \\
\hline & A & 10.27 & 10.294 & 12.37 & 16.37 & 12.82 & 16.13 \\
\hline & $\mathrm{R}^{2}$ & 0.9803 & 0.9240 & 0.8918 & 0.7947 & 0.8826 & 0.9087 \\
\hline
\end{tabular}
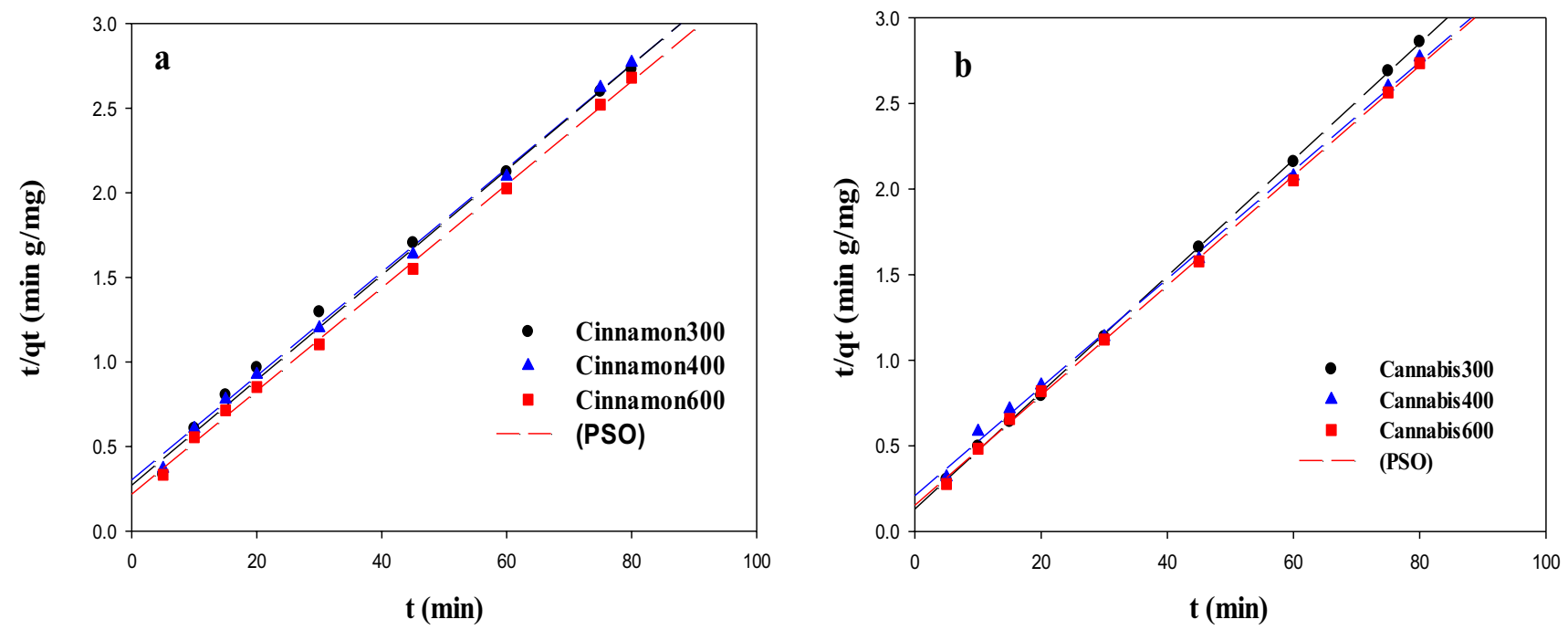

Fig. 10 PSO model for the adsorption of Cd(II) ions onto cinnamon 300, cinnamon 400, cinnamon 600 (a) and cannabis 300, cannabis 400, cannabis 600 (b)

and Fig. 10. Based on the data in Table 2, the PSO model revealed higher correlation coefficients $\left(R^{2}>0.9980\right)$ compared to PFO, E, and ID models for the adsorption action of $\mathrm{Cd}(\mathrm{II})$ ions onto cinnamon 300 , cinnamon 400 , cinnamon 600 , cannabis 300 , cannabis 400 , and cannabis 600 . Further, the amount of PSO rate constant $\left(k_{2}\right)$ for cinnamon 300 , cinnamon 400 , cinnamon 600 , cannabis 300 , cannabis 400 , and cannabis 600 were $0.0031,0.0035$, $0.0042,0.0088,0.0048$, and 0.0067 , respectively, pointing that the $\mathrm{Cd}(\mathrm{II})$ adsorption matched with PSO model. Furthermore, the PSO model expressed that the relation between $\mathrm{Cd}(\mathrm{II})$ ions in solution phase and cinnamon 300 , cinnamon 400 , cinnamon 600 , cannabis 300 , cannabis
400 , and cannabis 600 was chemisorption and biochars had a heterogeneous surface. The $\mathrm{q}_{\mathrm{e}}$ derived from the PSO model was more close to the empirical data. Finally, the adsorption action was in agreement with the PSO model when the primary $\mathrm{Cd}(\mathrm{II})$ concentration in the solution phase was small.

\subsection{Desorption studies}

Further evaluation of the adsorbent reuse is required from the economic and environmental points of view, particularly in industrial fields. Therefore, desorption estimates were performed in two steps in order to check the 

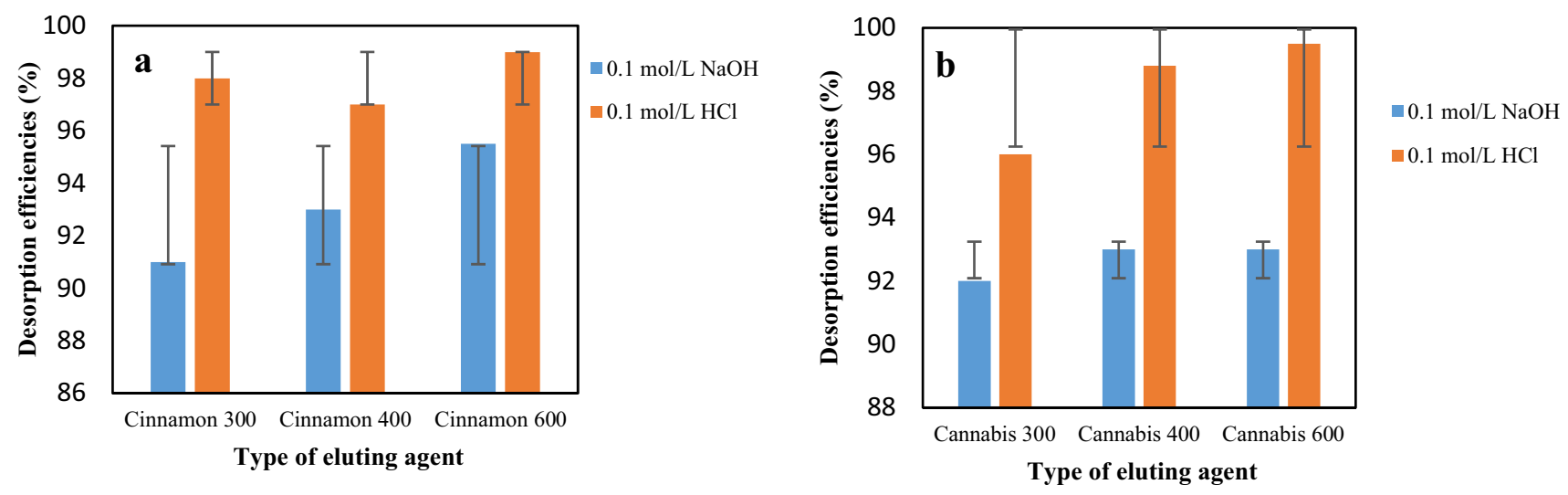

Fig. 11 Influence of type of eluting agent) with Standard deviation(s) on recovery (\%) for Cd(II ions adsorbed onto cinnamon 300 , cinnamon 400, cinnamon 600 (a) and cannabis 300, cannabis 400, and cannabis 600 (b)

reusability of the cinnamon 300 , cinnamon 400 , cinnamon 600 , cannabis 300 , cannabis 400 , and cannabis $600 . \mathrm{Cd}(\mathrm{II})$ adsorption analyses were accomplished by $10.0 \mathrm{~mL} \mathrm{Cd(II)}$ solution $60 \mathrm{mg} \mathrm{L}^{-1}$ and $0.1 \mathrm{~g}$ of each biochar with a $\mathrm{pH}$ of 7.0 and the equilibrium time of $60 \mathrm{~min}$ at $25^{\circ} \mathrm{C}$. Then, the $\mathrm{Cd}$ (II) ion loaded biochars were isolated and conveyed to $5.0 \mathrm{~mL}$ desorbing solvent $\left(0.1 \mathrm{~mol} \mathrm{~L}^{-1} \mathrm{HCl}\right.$ and $0.1 \mathrm{~mol} \mathrm{~L}^{-1}$ $\mathrm{NaOH})$, followed by determining the $\mathrm{Cd}(\mathrm{II})$ ion concentration by the ICP-OES after the desorption process. The desorption tests demonstrated that $\mathrm{Cd}(\mathrm{II})$ ions were recovered by using the solution of $0.1 \mathrm{~mol} \mathrm{~L}^{-1} \mathrm{HCl}$ from each of cinnamon 300 , cinnamon 400 , cinnamon 600 , cannabis 300 , cannabis 400 , and cannabis 600 with the values of 98,97 , $99,96,98.8$, and $99.5 \%$, respectively (Fig. 11). Also, Cd(II) ions were recovered by using the solution of $0.1 \mathrm{~mol} \mathrm{~L}^{-1}$ $\mathrm{NaOH}$ from each of cinnamon 300, cinnamon 400, cinnamon 600 , cannabis 300, cannabis 400, and cannabis 600 with the values of $91,93,95.5,92,93$, and $93 \%$, respectively. This confirmed the excellent capacity of the prepared biochars for eliminating the $\mathrm{Cd}(\mathrm{II})$ ions from water.

\section{Conclusions}

In the present study, cinnamon 300 , cinnamon 400 , cinnamon 600 , cannabis 300 , cannabis 400 , and cannabis 600 were fabricated to evaluate the influence of pyrolysis temperature on adsorption ability and surface properties of biochars derived from cinnamon and cannabis for the $\mathrm{Cd}(\mathrm{II})$ ion removal. The ideal condition for $\mathrm{Cd}$ (II) adsorption onto the biochars included a pH of 7.0, the adsorbent dose of $0.1 \mathrm{~g}$, and the temperature of $65^{\circ} \mathrm{C}$, supplying the $\mathrm{q}_{\max }$ of $147.05,153.84,158.73,133.33,144.92$, and $175.43 \mathrm{mg}$ $\mathrm{g}^{-1}$ for cinnamon 300 , cinnamon 400 , cinnamon 600 , cannabis 300 , cannabis 400 , and cannabis 600 , respectively. The cinnamon 600 and cannabis 600 revealed the highest adsorption of $\mathrm{Cd}(\mathrm{II})$ ions due to an increase in the pyrolysis temperature increased surface area of the adsorbents. The data were well modeled by the Langmuir model compared to Freundlich, Temkin, and Redlich-Peterson models while the kinetic fitted with the pseudo-second-order model and the quick adsorption of $\mathrm{Cd}$ (II) ions occurred in $60 \mathrm{~min}$. Eventually, the alkaline solution of $0.1 \mathrm{~mol} \mathrm{~L}^{-1} \mathrm{NaOH}$ and $0.1 \mathrm{~mol} \mathrm{~L}^{-1} \mathrm{HCl}$ were efficacious for $\mathrm{Cd}(\mathrm{II})$ ion desorption, as well as cinnamon 300 , cinnamon 400 , cinnamon 600 , cannabis 300 , cannabis 400 , and cannabis 600 recycling.

Acknowledgements The authors are grateful to the Hamedan Branch, Islamic Azad University for providing facilities to conduct and complete this study.

\section{Compliance with ethical standards}

Conflict of interest The authors declare that they have no conflict of interest.

\section{References}

1. Campos AFC, de Oliveira HAL, da Silva FN, da Silva FG, Coppola P, Aquino R, Mezzi A, Depeyrot J (2019) Core-shell bimagnetic nanoadsorbents for hexavalent chromium removal from aqueous solutions. J Hazard Mater 362:82-91. https://doi. org/10.1016/j.jhazmat.2018.09.008

2. Islam MA, Awual MR, Angove MJ (2019) A review on nickel(II) adsorption in single and binary component systems and future path. J Environ Chem Eng 7(5):103305. https://doi.org/10.1016/j. jece.2019.103305

3. Mukherjee T, Ghosh G, Mukherjee R, Das TK (2019) Study of arsenic (III) removal by monolayer protected silver nanoadsorbent and its execution on prokaryotic system. J Environ Manag 244:440-452. https://doi.org/10.1016/j.jenvman.2019.05.004

4. Zhang H, Dang Q, Liu C, Yu D, Wang Y, Pu X, Liu Y, Liang Y, Cha D (2019) Fabrication of methyl acrylate and tetraethylenepentamine grafted magnetic chitosan microparticles for capture 
of Cd(II) from aqueous solutions. J Hazard Mater 366:346-357. https://doi.org/10.1016/j.jhazmat.2018.12.006

5. Zhang Y, Yue X, Xu W, Zhang H, Li F (2019) Amino modification of rice straw-derived biochar for enhancing its cadmium (II) ions adsorption from water. J Hazard Mater 379:120783. https://doi. org/10.1016/j.jhazmat.2019.120783

6. Zhao J, Niu Y, Ren B, Chen H, Zhang S, Jin J, Zhang Y (2018) Synthesis of Schiff base functionalized superparamagnetic $\mathrm{Fe}_{3} \mathrm{O}_{4}$ composites for effective removal of $\mathrm{Pb}(\mathrm{II})$ and $\mathrm{Cd}(\mathrm{II})$ from aqueous solution. Chem Eng J 347:574-584. https://doi. org/10.1016/j.cej.2018.04.151

7. Esvandi Z, Foroutan R, Mirjalili M, Sorial GA, Ramavandi B (2019) Physicochemical behavior of penaeuse semisulcatuse chitin for $\mathrm{Pb}$ and $\mathrm{Cd}$ removal from aqueous environment. J Polym Environ 27(2):263-274

8. Sobhanardakani S, Jafari A, Zandipak R, Meidanchi A (2018) Removal of heavy metal $(\mathrm{Hg}(\mathrm{II})$ and $\mathrm{Cr}(\mathrm{VI}))$ ions from aqueous solutions using $\mathrm{Fe}_{2} \mathrm{O}_{3} @ \mathrm{SiO}_{2}$ thin films as a novel adsorbent. Process Saf Environ Prot 120:348-357. https://doi.org/10.1016/j. psep.2018.10.002

9. Sobhanardakani S, Zandipak R (2015) 2, 4-Dinitrophenylhydrazine functionalized sodium dodecyl sulfate-coated magnetite nanoparticles for effective removal of $\mathrm{Cd}$ (II) and $\mathrm{Ni}$ (II) ions from water samples. Environ Monit Assess 187(7):412

10. Zhu K, Wang X, Chen D, Ren W, Lin H, Zhang H (2019) Woodbased biochar as an excellent activator of peroxydisulfate for Acid Orange 7 decolorization. Chemosphere 231:32-40. https ://doi.org/10.1016/j.chemosphere.2019.05.087

11. Zhang YP, Adi VSK, Huang H-L, Lin H-P, Huang Z-H (2019) Adsorption of metal ions with biochars derived from biomass wastes in a fixed column: adsorption isotherm and process simulation. J Ind Eng Chem 76:240-244. https://doi.org/10.1016/j. jiec.2019.03.046

12. Li H, Xiong J, Xiao T, Long J, Wang Q, Li K, Liu X, Zhang G, Zhang $H$ (2019) Biochar derived from watermelon rinds as regenerable adsorbent for efficient removal of thallium(I) from wastewater. Process Saf Environ Prot 127:257-266. https://doi.org/10.1016/j. psep.2019.04.031

13. Rajapaksha AU, Ok YS, El-Naggar A, Kim H, Song F, Kang S, Tsang YF (2019) Dissolved organic matter characterization of biochars produced from different feedstock materials. J Environ Manag 233:393-399. https://doi.org/10.1016/j.jenvman.2018.12.069

14. Jack J, Huggins TM, Huang Y, Fang Y, Ren ZJ (2019) Production of magnetic biochar from waste-derived fungal biomass for phosphorus removal and recovery. J Clean Prod 224:100-106. https ://doi.org/10.1016/j.jclepro.2019.03.120

15. Zhao Z, Nie T, Zhou W (2019) Enhanced biochar stabilities and adsorption properties for tetracycline by synthesizing silicacomposited biochar. Environ Pollut 254:113015. https://doi. org/10.1016/j.envpol.2019.113015

16. Choudhary B, Paul D (2018) Isotherms, kinetics and thermodynamics of hexavalent chromium removal using biochar. J Environ Chem Eng 6(2):2335-2343. https://doi.org/10.1016/j. jece.2018.03.028

17. Wang L, Wang Y, Ma F, Tankpa V, Bai S, Guo X, Wang X (2019) Mechanisms and reutilization of modified biochar used for removal of heavy metals from wastewater: a review. Sci Total Environ 668:1298-1309. https://doi.org/10.1016/j.scito tenv.2019.03.011

18. Lin L, Zhang G, Liu X, Khan ZH, Qiu W, Song Z (2019) Synthesis and adsorption of FeMnLa-impregnated biochar composite as an adsorbent for As (III) removal from aqueous solutions. Environ Pollut 247:128-135

19. Goh CL, Sethupathi S, Bashir MJ, Ahmed W (2019) Adsorptive behaviour of palm oil mill sludge biochar pyrolyzed at low temperature for copper and cadmium removal. J Environ Manag 237:281-288

20. Shafiee $M$, Foroutan $R$, Fouladi $K$, Ahmadlouydarab M, Ramavandi $B$, Sahebi S (2019) Application of oak powder/Fe $\mathrm{O}_{4}$ magnetic composite in toxic metals removal from aqueous solutions. Adv Powder Technol 30(3):544-554

21. Foroutan R, Peighambardoust SJ, Mohammadi R, Omidvar M, Sorial GA, Ramavandi B (2020) Influence of chitosan and magnetic iron nanoparticles on chromium adsorption behavior of natural clay: adaptive neuro-fuzzy inference modeling. Int J Biol Macromol 151:355-365

22. Langmuir I (1918) The adsorption of gases on plane surfaces of glass, mica and platinum. J Am Chem Soc 40(9):1361-1403

23. Freundlich $\mathrm{H}$, Heller W (1939) The adsorption of cis-and transazobenzene. J Am Chem Soc 61(8):2228-2230

24. Mane VS, Mall ID, Srivastava VC (2007) Kinetic and equilibrium isotherm studies for the adsorptive removal of Brilliant Green dye from aqueous solution by rice husk ash. J Environ Manag 84(4):390-400

25. Temkin M, Pyzhev V (1940) Recent modifications to Langmuir isotherms

26. Yin G, Song X, Tao L, Sarkar B, Sarmah AK, Zhang W, Lin Q, Xiao $\mathrm{R}$, Liu Q, Wang H (2020) Novel Fe-Mn binary oxide-biochar as an adsorbent for removing Cd (II) from aqueous solutions. Chem Eng J 389:124465

27. Chen G, Wang C, Tian J, Liu J, Ma Q, Liu B, Li X (2020) Investigation on cadmium ions removal from water by different raw materials-derived biochars. J Water Process Eng 35:101223

28. Zhou X, Zhou J, Liu Y, Guo J, Ren J, Zhou F (2018) Preparation of iminodiacetic acid-modified magnetic biochar by carbonization, magnetization and functional modification for Cd (II) removal in water. Fuel 233:469-479

29. Zhu F, Li L, Xing J (2017) Selective adsorption behavior of Cd(II) ion imprinted polymers synthesized by microwave-assisted inverse emulsion polymerization: adsorption performance and mechanism. J Hazard Mater 321:103-110. https://doi. org/10.1016/j.jhazmat.2016.09.012

30. Shang Z, Zhang L, Zhao X, Liu S, Li D (2019) Removal of Pb(II), $\mathrm{Cd}$ (II) and $\mathrm{Hg}$ (II) from aqueous solution by mercapto-modified coal gangue. J Environ Manag 231:391-396. https://doi. org/10.1016/j.jenvman.2018.10.072

31. Foroutan R, Mohammadi R, Farjadfard S, Esmaeili $H$, Saberi M, Sahebi S, Dobaradaran S, Ramavandi B (2019) Characteristics and performance of $\mathrm{Cd}, \mathrm{Ni}$, and $\mathrm{Pb}$ bio-adsorption using $\mathrm{Cal}$ linectes sapidus biomass: real wastewater treatment. Environ Sci Pollut Res 26(7):6336-6347

32. Azizian S (2004) Kinetic models of sorption: a theoretical analysis. J Colloid Interface Sci 276(1):47-52

33. Plazinski W, Rudzinski W, Plazinska A (2009) Theoretical models of sorption kinetics including a surface reaction mechanism: a review. Adv Coll Interface Sci 152(1-2):2-13

Publisher's Note Springer Nature remains neutral with regard to jurisdictional claims in published maps and institutional affiliations. 